The International Journal of Social Sciences and Humanities Invention 5(05): 4765-4768, 2018

DOI: DOI: 10.18535/ijsshi/v5i6.01

ICV 2015: 45.28

ISSN: 2349-2031

(C) 2018, THEIJSSHI

Research Article

\title{
Food Security and Sustainable Agricultural Development in Nigeria
}

\author{
Dr. (MRS.) Louisa N. Amaechi \\ (Directorate of General Studies) Federal University Of Technology, Owerri, Imo State,Nigeria.
}

\begin{abstract}
Food security is the ability to provide enough food to the entire population of a particular state or country at all times. The paper discussed the concept of food security, various ways, policies and strategies to be embarked upon by the government for sustainable agricultural development to ensure adequate food security. The need for agricultural sustainability was examined. It also discussed the socio-economic implication of sustainable agriculture and its challenges. The paper recommends an improved policy execution, monitoring/ evaluation and support to agriculture by the Federal government as the measures for a sustainable agricultural development in Nigeria.
\end{abstract}

Key words: Food security, agricultural sustainability and government intervention

\section{INTRODUCTION}

Every human being needs food not just for energy giving but to sustain life in general. The issue of food security should not be over emphasized because of its necessity to life through a sustainable agricultural development. Agriculture was the major source of the country's economy and source of foreign exchange before the era of oil discovery in Nigeria. It was after the discovery of oil that the agricultural production gradually dropped and lesser attention given to it by the federal government, this led to the challenge of food insecurity, unemployment and youth restiveness at Niger Delta communities where oil is explored and agric farm destroyed.

Agricultural neglect by the federal government also generated poverty and some social ills in our society. It was reported that half of the African population live below the extreme income poverty line of less than one dollar per day. (World Bank 1998). It was reported that in sub-saharan Africa, average annual income is $\& 1640$ compared to $\& 31,872$ as it is observed in U.S. Sub-saharan Africa has $10 \%$ the world population but nearly $25 \%$ of all are malnourished and one of every three African suffers malnutrition (bread for the world 1997-1999).

Food security according to FAO (1984) is all people at all times having the physical, social and economic access to sufficient safe and nutritious food in order to meet their dietary needs and food preferences for an active and healthy life. (World Food Summit) sees food security as availability of people to nutritionally adequate and safe water and food. Igba (2003),also reported that food security, is the relationship between the total number of people as against food available at a particular people on a time. It can as well be seen as a state of affairs where all people at all times have access to adequate supply of food. Human foods and health security in the past was based on hundred of foods and medical plants. As civilization advanced, food security system started depending on fewer and fewer crops. Such a narrow mix of food crops made food production system vulnerable to biotic and abiotic stress and weather conditions. In the last fifty years, the concept of food security undergone considerable elaboration and refinement.

The acute food security witnessed in the nineteen fifties China, Bangladiesh and some African countries in seventies and eighties called for the need for food security attention The depletion of forest area in many developing countries also signal the desired interest and achieve in food production through enhanced productivities. (Aibangbe 2011) and (Swaminethan 1997) are of the view that from 1970 to date, Nigeria has been suffering from food security and poverty. There has been steady increase in the prices of food over the years and deterioration in the living standard. Aibangbe (2011) notes that the consequences is that the income of most people no longer sustain them in families. The key Component of food security is production of availability of nutritionally adequate and safe food and access or capacity to acquire nutritionally adequate and safe food. To achieve food security in Nigeria, the following indices must be observed, thus; availability, affordability, accessibility and utilization of food.

Onwukwe (2011), is of the view that for sustainable agriculture to occur for food security In Nigeria, rural farmers must be encouraged by the government. Rural development will as well encourage agricultural sustainability such as provision of amenities, infrastructure, telecommunication, electricity, silo and irrigation (UNDP, 2001)

Farmers should not only adopt any available method of storage and processing measures, but should try to reduce value added produce from every part of plant or animal. Post harvest technology assumes particular importance in the case of Perishable commodities like fruits, vegetables, milk, egg, fish and other animal products and processed food. There must be a mismatch between production and post-harvest technology to 
affect adversely both producers and need to be provided and improved to Nigerian society. For food security, Such food processing industries should be provided and promoted in the rural areas to improve employment for the rural dwellers.

It is equally important to give consideration to the composition of the farming system such as soil components, water availability, agro-climatic features, home needs and above all marketing facilities and opportunities will help to determine the choice of crops, farm animals and acquire culture systems. Crops such as cassava, maize, yarn, coco-yarn, potatoes, rice, vegetable and other food items can be improved. Small and large ruminants will have a particular advantage among farm animals since they can live largely on crop biomass. Farmers need to have media publicity on new method of farming and existence of new products, technology and other necessary information and assistance by the government, Aibangbe (2011) 340 .

\section{Sustainable Agricultural Development}

\section{A conceptual explanation}

Sustainability of agriculture is the maintenance and improvement of agricultural development in order to sustain the livelihood in that nation and their future generation (Ayinde 2008) agriculture is one of the socio-economic resources in any nation that is used to preserve life. A sustainable development implies an active role for government in efficient and equitable management of natural and environmental resources, Rearson (2000). A sustainable agriculture is a sustainable economy.

Pigou (cited in Krutilia. 1967), stressed that it is the duty of the government as the trustee for present, future or unborn generations to watch over and if need be, by legislative enactment to defend the exhaustible natural and agricultural resources from rash and reckless spoliation. The business council for sustainable development stated that we cannot continue in our present methods of using energy, managing forest, farming, protecting plant and animal species, managing urban growth and producing industrial goods to sustain our economy. Sustainable agricultural development is the ability of the present and future generation to meet their agricultural needs, Karpagan (2010). Also sustainable socio-economic development as one which is directly concerned with increasing the natural standard of living of the poor at the grassroots level which include the increase in food, real income, educational services, health care, sanitation, water supply and the like (Karbugan, 2010).

Sustainable socio-economic and agricultural development is also the ability of the present generation to device a means of improving and using depletible resources such that future generations will not suffer more than the present ones, (Tietenberg, 2010). This sustainable development aims at the creation of sustainable improvement in the quality of agricultural development and other economic sector of the country.

Sustainability in itself is fairness regarding the treatment of present and future generations and contends that for ethical reason exploitation of resources should not leave future generation worse than the current sustainability also requires manage the resources base such that the average quality of life, ensures can potentially be shared by all future generation (Arshen 2010).

The agricultural sustainability will help to reduce poverty, hunger, starvation, lack, suffering, untimely death, infection and diseases in Nigeria environment.

Agriculture should be one of the most important factors for any meaningful socio-economic development of any nation. The sustainable socio-economic development has three basic interrelated components; economic that requires societies to pursue growth paths that generate optimal flow of income, while maintaining their basic stock of man-made human and natural capital and internalizing of all cost including the environmental type associated with production and consumption in order to satisfy the basic needs of the people of which food is the number one.

\section{THE NEED FOR FOOD SECURITY AND SUSTAINABLE AGRICULTURE}

A country with abundant food tends to live a happier way of life. Improves the living standard of people, reduces social ills and improves health condition of people especially the children and vulnerable ones in the society. It projects the image of people and community favourable to the international community. It helps to create a conductive atmosphere for a healthy governance. It arrest youth restiveness because a hungry man is an angry man. A sustainable agricultural development gives hope for a better living for the future generation and creates enabling environment for good governance.

It gives room for consumers to make choice of the type of food to consume. Food security reduces spread of diseases and problems in the society and increase cooperation, love and understanding among people. The sustainable agriculture helps to boost the morale of the leaders, creates opportunities for employment and gives room for rural development especially, in the area of social amenities and infrastructural development in agricultural centered environment. It increases a country's foreign exchange and provides avenue for the supply of raw materials to the local industries. It gives opportunity to countries to increase their production capacity to the goods they have a comparative advantage over other nation. It sustains livelihood of many in any living nation, improves people mental faculty and makes a way for free and fair election in a democratic system.

It makes a nation to be self reliance and dependless on importation of foreign products.

\section{Agricultural sustainability in Nigeria}

For one to have and establish an affective sustenance of agricultural economy in the country, there must be an attitudinal change by the government through diversification of the country's economy to other sectors of economy most especially the agriculture and industries. 
Change of government policy from agricultural neglect to agricultural empowerment at all levels and at all times (example) in china, there was agricultural revolution when hunger was too much in china as the result of their over population. This principle of agricultural revolution boosted other sectors of Chinese economy including the science, technology and industries which are fed with output of agriculture.

Assistance of banks towards agricultural sustainability through the release of credit facilities. Agricultural equipment's, machines. Seminars, workshop and training and retraining of agric officers and experts for greater output need to be facilitated by the government. The government should as well make available some agricultural inputs such as land, fertilizer machine, tractors, harvestor, grass cutter, seeds and seedlings to every farmer.

Formulation of effective and powerful agricultural policies and programmes that need to be backed up with effective monitoring, supervision and evaluation exercise in order to make it to be fruitful exercise and venture is urgently needed. It was rightly pointed out that before any economic growth occurs there must be a strong policy backing up the programme and project should as well be provided such as silo for the preservation of the surplus agricultural products by every farmer, irrigation techniques should be encouraged by the government to the farmers.

The government should encourage the study of agriculture in the educational curriculum as a compulsory subject to everybody at all levels of study while the provision of insecticides should be made available to the farmers.

The lending interest rate for the agric farmers should be reviewed and reduced by the agric banks and more agricultural banks established for the purpose of making und available at all times for the farmers. The farmers' cooperative society should be strengthened and encouraged by different levels of government. Putting agricultural development ahead of any other economic sector in planning will help to uplift that sector of economy by the federal government (Ayinde, 2008).

The UN mandated every developing country to start up a millennium development goal programme on food security to eradicate hunger all over the world. Nigeria started agricultural development Programme on that effect called FADAMA project.

The development of agricultural "FADAMA" programme had a target of ensuring adequate food security in the year 2015 for the entire country but failed. Therefore, the inability of the Nigerian federal government to achieve the MDGs objective of ensuring food security in the country for the year 2015 must be studied and the issue that contributed to its failure avoided and adjusted or improved, Nigerians need urgent help and restructuring of agric economy from world powers and world banks to address the current economic challenge on poverty and food insecurity in the country. The current Buhari's regime in Nigeria re-introduced a fresh food in security and hunger in the country.

\section{Government Intervention, Policies and Programmes}

Shortly after independence in Nigeria, Nigeria was still engaged fully in the production and exportation of agriculture products which employed both the illiterate, semi-illiterate and literate citizens of the country. The Federal government in order to sustain the agricultural tempo established a board called, the agricultural marketing board which was charged with the function of the control of marketing the agricultural products. Later crude oil was discovered and there was a little shift of attention from agricultural economy to the oil economy which later affected the agric sector of the country's economy.

The little neglect in agricultural economy generated poverty, hunger, increase in unemployment, social insecurity, and other associated problems. This called for the federal government's attention to sustain agricultural economy through the enactment of some policies to revive the sector. Since agriculture provides raw materials that can feed our local industries and arrest hunger in the society, some agricultural policies such as: Green Revolution, operation feed the nation (OFN).

The Structural Adjustment programme (SAP), Back to land agricultural scheme for graduates, River-basin Development authorities were part of the initiatives. Others agric policies include, the establishment of the Nigerian agricultural cooperative and rural development scheme, the peoples Bank to support Agric, Nigerian agricultural cooperative Bank, the family Economic Advancement programme which emerged in 2000 and later took off in 2001 with the ultimate aim of providing an easy access to credit facilities and agricultural input to encourage food security. The bank of industry, which was the integration of Nigerian development bank, the Nigerian bank for commerce and industry and the National economic reconstruction fund were established to encourage agric and other business enterprises. The directorate for food, road and rural infrastructure (DFRRI), the oil minerals producing area development communities/ commission were established to improve in Agriculture and to provide cassava floor processing scheme among other establishments (Ayinde 2008, Eto and Ogbazi, 1990).

In recent time, among other programme of MDG was the food security which was mandated by UN for all developing world to start a programme that will enable their countries to achieve the MDG goals on food security. This made Nigeria to embark upon the FADAMA Agric project. The target year which was 2015 has come and gone, yet. Nigeria is yet to arrest food insecurity. Even with all their agricultural policies and programmes since independence, to achieve food security and maintain sustainable agricultural development failed in Nigeria. There must be close monitoring and evaluation of agric policies and programmes, this is because of diversion of the credit facilities and loan which is given to people without proper utilization, it was observed that this agric grants for agricultural development do not go to the real farmers who 
may utilize for its main purpose, It goes to the wrong hands and greedy officers who divert it for their selfish purpose for acquiring more flashy cars, buy more-buildings and marry more women.

\section{Problem of Nigerian Agricultural Economy}

The Nigerian political leaders lack effective and powerful political will to sustain the agricultural economy of the nation. Most of the leaders do not see or experience the insecurity of food, poverty or unemployment and their associated social insecurity as serious issues to be talked, because of the nature of their security outfit as political office holders, it does not concern them if great population of the country's citizen go on hungry.

The world development report (2001\&2008) rightly pointed out that a number of Nigerian population live in poverty and hunger and cannot earn more than 2.5 dollar per day to sustain their livelihood. The basic interest of many political leaders in Nigeria is economic acquisition. The politics of making rich or acquiring wealth by all means becomes the order of the day. This made it impossible for absolute separation of economic acquisition from politics. This issue affected virtually every aspects of the country's economy most especially the agriculture. The extent of the success of the economy depends largely on the planning and projections of the government for the future. If muscles is always been flexed between different aims of government, in all cases especially where the development of economy is concerned, the situation may be lack of trust in political and economic arrangement to the pleasure of those who fish in troubled waters.

\section{Challenges of Food Security And Sustainable Agricultural Development In Nigeria Include}

Soil problems, climatic condition, forest zone challenges, policy change and lack of effective implementation and evaluation strategy in agriculture policy.

\section{Conclusion}

Nigeria is a country that is increasing in population on yearly basis and need to do something in order to sustain the livelihood of its increasing population. In no distance time oil may disappear or reduce as the main source of the foreign exchange and the only alternative will be agriculture. Nigerian government therefore should re-visit its agricultural policies and programme in order to revive agricultural economy in order to provide adequate food security in the country.

\section{Recommendation}

The provision of government policies, programmes and activities for agricultural production in Nigeria will help to improve food security

programme, reduce poverty and unemployment. Agriculture as a subject should be made a compulsory subject for students at all levels of study.

Agricultural inputs and credit facilities should always be made available to rural farmers. An improved agricultural facilities such as tractors, harvestor and other equipment should always be made available to farmers. The government should as well monitor the facilities given to farmers to ensure effective use of them.

\section{REFERENCES}

[1] Aboyade O. (1999) Provision of Information for Rural development, Ibadan foundation.

[2] Aibangbe M.O (2011) Effective ways of achieving sustainable poverty and food security in Nigeria.

[3] Ashein G.B (2010) Defining sustainability when resource management does not have deterministic consequences mimeo. Department of Economics. University of Oslo.

[4] Ayinde, O.E. (2008) Empirical Analysis of Agricultural growth and unemployment in Nigeria. African journal Agric. Res. 3(7) 465.

[5] Bread for the world 1997-1999 percent of world's mal nourished action against hunger, incidence of African malnutrition.

[6] Eton, E.G. and Ogbazi C. (1990). The role of women in Nigerian

[7] agricultural production and development. Challenges of agriculture in natural development. Faculty of agriculture, UNN.

[8] FAO (1984) "Forward looking strategies, women in agriculture and rural development Rome.

[9] Igba, C.E. (2003) Family and food insecurity in Nigeria. Journal of Home economics. Researcher 5(2) January, 2003 UNEP, 1999.

[10] Karpagan, M. (2010) Environmental Economics New Delhi: Sterling Publications.

[11] Krutilla (1967) sustainable development, concept and issues. London free press.

[12] Mishkin, S.F (2007) the economy of money, banking and financial markets U.S. http/www.pearsoned.com/ege/permission/htm

[13] Pearson, C.S. (2000) Economics and the Global Environment Cambridge university press.

[14] Swaminathan, M.S. (1997) Agricultural Production for Future food security science reportan, August 1997.

[15] Tieteberg (2010) Environmental and Resources Economics. London Pearson education.

[16] United Nations Development Programme (2001) Food Security and Agriculture.

[17] World Bank (1998) Income Expressed As GDP per Capita PPP US \&. 